\title{
Dielectric/Metal/Dielectric flexible transparent electrodes, from smart window to semi-transparent solar cells.
}

\author{
J. C. Bernède ${ }^{1}$, L. Cattin ${ }^{2}$. \\ 1- MOLTECH-Anjou, CNRS, UMR 6200, Université de Nantes, 2 rue de la Houssinière, \\ BP 92208, Nantes, F-44322, France. \\ 2- E-Mail : jean-christian.bernede@univ-nantes.fr \\ $3-$ \\ 2- Institut des Matériaux Jean Rouxel (IMN), Université de Nantes, CNRS, UMR 6502, \\ 2 rue de la Houssinière, BP 92208, Nantes, F-44322, France. \\ E-Mail : $\underline{\text { linda.cattin-guenadez@univ-nantes.fr }}$
}

\begin{abstract}
The present manuscript is dedicated to In free transparent conductive and flexible heterostructure electrodes. The new electrodes correspond to dielectric/metal/dielectic (D/M/D) multilayer structures deposited under vacuum. In the present work, after a fast review of the general properties of D/M/D electrodes using Ag as metal, we then develop the study of $\mathrm{D} / \mathrm{Cu} / \mathrm{D}$ multilayer structures. We propose to substitute $\mathrm{Cu}$ to $\mathrm{Ag}$, because it is far cheaper. However, Cu having tendency to diffuse into many dielectrics it is difficult to obtain stable electrodes. We show that using Cu:alloys, i.e. Cu:Ni and $\mathrm{Cu}$ :Al, as metal it is possible to decrease significantly the Cu ions diffusion and to increase significantly the stability of the multilayer electrodes with $\mathrm{Cu}$. Finally, we show that when these electrodes are used as anode in organic photovoltaic cells, they can allow achieving efficiency similar to that obtained with ITO.
\end{abstract}

Keywords: Indium tin oxide free electrode; Transparent conductive electrode; Organic photovoltaic cells;

\section{INTRODUCTION}

In order to minimize global warming, it is necessary, not only to substitute renewable energies for fossil fuels, but also to reduce our energy consumption. Actually, traditional windows waste about 30 percent of the energy used to heat and cool the entire building. Therefore, coupling "smart windows" that switch between transparent and opaque with semitransparent photovoltaic cells would cumulate energy economy and renewable energy production. Smart windows have been around for decades they usually employ so-called electrochromic windows, which require an outside power source to change colour [1]. Coupled with semitransparent solar panels, they will not only not need external energy input, but they will also provide some [2].

Beside their flexible, lightweight, the most exciting thing about organic semiconductors is that it's possible to design molecules that are coloured or quite transparent, which allows growing semi-transparent photovoltaic cells. Concerning the pronounced absorption features of various absorber molecules used in organic photovoltaic cells (OPVCs), devices can be designed to transmit light in a specific spectral range. Thereby, coloured seethrough photovoltaic elements (e.g. windows or coloured semi-transparent curtains) are possible [2]. Today, there is a growing interest in building integrated photovoltaic (BIPV). Using OPVCs that can transmit light, by simple device fabrication process onto flexible substrates, is most suitable for building integrated solar power generator. 
Such semi transparent devices imply that the two electrodes of the cells are transparent. In the same way, smart widows need also transparent conductive electrodes. To do these transparent conductive electrodes it is usual to use a transparent conductive oxide (TCO). There is a growing demand for transparent and conductive electrodes (TCE) due to the spectacular growth of the optoelectronic devices market: flat screens, photovoltaic cells, contact screens, light-emitting diodes and also devices illumination. Today, more than $80 \%$ of the TCE needs used each year are covered by thin films of tin-doped indium oxide (ITO). Generally, ITO thin films are deposited by magnetron sputtering and then the properties of ITO films are optimized by heat treatment at $250 \circ 0^{\circ} \mathrm{C}$ or higher [3]. If ITO is the ECT most often used it is that it has many advantages, such as excellent optical properties (a large transmission of light in the visible range) and good conductivity. All this makes it the most efficient transparent conductive oxide in optoelectronic devices.

However, it also has certain disadvantages such as the scarcity of indium, the aggressive techniques of ITO deposits for organic matter and its mechanical fragility ... Regarding the rarity of indium, it can be noted that the ITO film is very thin, between 100 and $300 \mathrm{~nm}$ and, in the short term, there is enough indium on the earth to meet the demand. But this should not hide the foreseeable shortage in the medium term. Above all, the cost of indium is very high because it is extracted as a by-product of $\mathrm{Zn}$ extraction for a very low concentration. This is a first motivation, economic in nature, to look for alternative TCEs: New Transparent Conductive and Flexible Electrodes (NTCFE).

But they are also scientific motivations. If ITO is nowadays the most used, it is not without presenting some practical disadvantages. Nowadays, there is a growing demand for flexible optoelectronic devices made from plastics. The mechanical properties of ITO make it unsuitable for the use of flexible substrates; it is indeed brittle because of its ceramic structure [4-7].

Its coefficient of thermal expansion is unsuited to that of polymers commonly used as flexible substrates [5].

Deposition techniques for ITO and other OTCs require the use of destructive processes (sputtering and / or substrate heating) for organic products, which precludes the use of these TCOs as an intermediate or top electrode in OPVCs [8].

All this makes it necessary to work on the development of new transparent conductive and flexible electrodes (NTCFE).

This NTCFE must meet certain specific conditions:

- Optical transmission (especially in the visible) and high conductivity.

- It is desirable that its extraction work is easily scalable.

- Its constituent elements must be abundant and environmentally neutral. The properties of the electrode must be stable over time.

- The techniques used for its deposition should be as gentle as possible and at room temperature.

- The manufacturing process must be transferable to the industry; a R2R (roll-to-roll) deposition process would be desirable

More precisely, the sheet resistance of the NTCFE, the alternative electrode, should be of the order of $5 \Omega$ /sq, its optical transmission in the visible higher than $80 \%$, its work function, $\mathrm{W}_{\mathrm{F}}$, should be able to be modulated between $4 \mathrm{eV}$ and more than $5 \mathrm{eV}$. It will have to stand with radii of curvatures of the order of $1.5 \mathrm{~cm}$ without its performance is degraded by more than $10 \%$. Its adhesion to the substrate, or to the lower layer, must be high and compatible with a plastic substrate.

Several possibilities of substitution materials are possible, some of which have already been studied extensively. First, there are other transparent oxides such as fluorine-doped $\mathrm{SnO}_{2}$ (FTO) and aluminum-doped $\mathrm{ZnO}$ (AZO) [9]. However, to obtain acceptable conductive and 
transparent layers it is necessary to use the same deposition techniques as those of the ITO, thus damaging to organic materials.

Moreover, their work function is much weaker than that of the ITO and the $\mathrm{ZnO}$ is not stable in time. If chemical voices, such as "Sol-Gel" processes have been proposed for depositing these oxides, these processes require thermal treatments that are not very compatible with organic materials. If we add to this that the experiment shows that the organic optronic components using these OTC (FTO and AZO) show generally lower performances than those obtained with the ITO, it will be understood that it is not a real alternative to ITO.

An "all-polymer" process is also conceivable [10]. PEDOT:PSS (poly(3,4ethylenedioxythiophene) polystyrene sulfonate) is the transparent conductive polymer the most often used as ITO free electrode, it is known to be a highly efficient buffer layer at the anode / organic electron donor interface in organic optoelectronic devices. PEDOT:PSS electrodes exhibit good flexibility [11], which made them compatible with roll-to-roll process [12]. Nevertheless, the resistivity of PEDOT:PSS is a little too high, different attempts have been dedicated to improve the PEDOT conductivity [13], while alternative deposition techniques are probed to avoid spin coating, which is not adequate for industrial processes [14].

Similarly, graphene is under investigation [15]. If the feasibility of small surface components has been shown, without equaling the ITO, it seems difficult to transpose this to large areas given the realization techniques of these electrodes and the factors limiting the simultaneity of their transparency and their conductivity.

In the organic domain, carbon nanotubes [16] also have been widely studied and it seems difficult to obtain electrodes both conductive and transparent which limits the scope of this type of electrode. Moreover the poor adhesion to the substrate of the carbon nanotube and the high surface roughness of their layers make it difficult to use these nanotubes as TCE [17]. On the other hand, replacing carbon nanotubes with metal nano-wires have shown great promise, due to the fact that it is easier to grow transparent and conductive metal nano-wires films $[18,19]$. Nevertheless problems of adhesion and surface roughness are still present. Another possibility is the use of ultra-thin metal films [20]. These layers have received renewed interest because of their high flexibility. Moreover, the new concept of bilayer thin metal films allows obtaining higher performances than those of equivalent single metal layer. $[21,22]$. Nevertheless, when, in order to obtain high conductivity, the metal film thickness is increased, the reflexivity of the layer increases significantly.

Another voice consists is the use of Dielectric / Metal / Dielectric (D/M/D) superimposed thin film structures. Indeed, among the possible routes, the use of multi-layer structures opens up promising prospects [4, 9, 23-33], which makes that teams all around the world have begun to explore this possibility. We ourselves have initiated work on this type of structures [34]. In these structures, the high conductivity of the metal allows achieving very small sheet resistance, while the high refractive index of the dielectric permits to decrease the light reflection of the metal in the visible range.

For the development of semi-transparent organic solar cells, because of these various possibilities, different concepts have been presented relating the transparent top electrode [2]. It has been shown that transition metal oxides, which are often the dielectric in $\mathrm{D} / \mathrm{M} / \mathrm{D}$ multilayer structures, can be used successfully in OPVCs. Actually, for organic solar cells, transition metal oxides (TMOs), like $\mathrm{WO}_{3}$ or $\mathrm{MoO}_{3}$, have been used as interlayers between organic layers and electrodes to allow efficient hole extraction at the anode side [35]. Moreover, thin layers of TMOs have also been applied as interconnect layers for stacked tandem solar cells [36, 37], so is it for $\mathrm{MoO}_{3} / \mathrm{Ag} / \mathrm{MoO}_{3}$ structures in parallel tandem organic solar cells [38]

These highly transparent transition metal oxides can be thermally evaporated on top of organic without introducing damages, which made them suitable as buffer layers... and intermediate or top 
$\mathrm{D} / \mathrm{M} / \mathrm{D}$ electrode. On the other hand, it is also well known that transition metal oxide such as $\mathrm{WO}_{3}$, $\mathrm{MoO}_{3} \ldots$ are very efficient as fast and reproducible colour change films in smart window $[1,39]$. Beyond the OPVCs, it should be noted that DMDs are also effective in other types of solar cells such as perovskite or silicon based solar cells.

In recent years, thanks to crystalline materials called perovskites a new family of performing solar cells was put in evidence, in such solar cells transition metal oxide were used as hole extracting layer [40]. Moreover, perovskites may be used in smart window, keeping them clear on cold days, but turning them dark in the hot summer sun. For instance, it was shown that solar window that turns opaque and produces electricity when heated can be achieved using perovskite as active layer [41]. It makes that perovskites offer a possible route to smart windows and solar windows at the same time.

Also, the high efficiency of transition metal oxides as hole collector inspired new possible investigations in the field of silicon (c-Si) solar cells. Actually, if this field is well known, as shown by the fact that c-Si technology dominates strongly the solar panel market, it could be interesting to avoid some steps, such as doping to form the junction, what is complex and energy consumer, or which needs the use of hazardous gas precursor. Lower thermal budgets and simplified fabrication process could be achieved using silicon heterojunction structures, D/M/D electrodes being used as hole-selective contacts [42, 43]. Similarly, investigations are under way with amorphous silicon solar cells [44].

All that makes that $\mathrm{D} / \mathrm{M} / \mathrm{D}$ structures seem well suited to the realization of selfpowered smart windows [45]. However, it is necessary that not only these electrodes are transparent and conductive, but also that these properties are stable over time. Moreover they must have a good adhesion to plastic substrates and they must be less brittle than classical TCO. It must be admitted that although the optical and electrical properties of these structures are systematically studied, this is not the case with regard to these other properties. Therefore, in the present work, after recalling some generalities about optical and electrical properties of $\mathrm{D} / \mathrm{M} / \mathrm{D}$ structures we will investigate more precisely the adhesion, flexibility and mainly stability of these multilayer structures. Finally, we will show that D/M/D- NTCFEs appear as one of the most promising alternative to ITO to grow window electrodes for emerging thin film solar cells in building integrated photovoltaics.

\section{EXPERIMENTAL DETAILS}

\subsection{D/M/D multilayer structures realization and characterization}

$\mathrm{D} / \mathrm{M} / \mathrm{D}$ structures were deposited on glass or $150 \mu \mathrm{m}$ thick PET (polyethylene terephthalate) substrates using simple sublimation/evaporation technique. Before deposition, the PET substrates were submitted to a specific surface treatment in order to obtain conductive and adherent multilayer structures. After cleaning by a detergent, the PET substrates were rinsed in running distilled water. Then they were treated in $0.5 \mathrm{M} \mathrm{NaOH}$ at $90^{\circ} \mathrm{C}$ for half an hour, rinsed again with distilled water and finally dried in an oven and introduced into the deposition apparatus. In the case of glass substrates, after scrubbing with soap, substrates were rinsed in running deionised water. Then, they were dried with an argon flow, heated for $10 \mathrm{~min}$ at $100^{\circ} \mathrm{C}$, and finally loaded into a vacuum chamber $\left(10^{-4} \mathrm{~Pa}\right)$. The size of the samples was $2.5 \mathrm{~cm} \times 2.5 \mathrm{~cm}$ (or $1.6 \mathrm{~cm}$ )

The layers were successively deposited onto substrates at room temperature, using tungsten crucibles, loaded with dielectric powders or metal wires. The bottom dielectric thickness was varied from 0 to $50 \mathrm{~nm}$, while the top dielectric layer was between 5 and $35 \mathrm{~nm}$. After deposition of the bottom layer, at a deposition rate of $0.03-0.06 \mathrm{~nm} / \mathrm{s}$, metal film was deposited by thermal evaporation at a deposition rate of $0.1-0.6 \mathrm{~nm} / \mathrm{s}$, depending on the metal. Subsequently, the top dielectric layer was deposited at identical conditions to those used for the bottom layer. Both, film thickness and deposition rate, were monitored with a 
quartz crystal microbalance. It must be noted that the deposition apparatus is equipped with five deposition sources which allows varying the configuration of the multilayer structure. A typical scheme of a $\mathrm{D} / \mathrm{M} / \mathrm{D}$ structure is drawn in Figure 1.

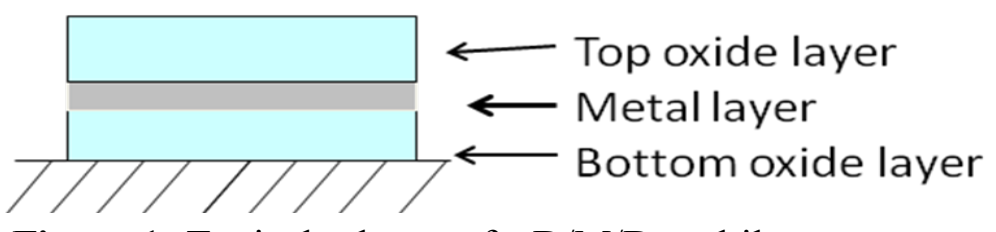

Figure 1: Typical scheme of a D/M/D multilayer structure.

Sheet resistance Rsh, of the $\mathrm{D} / \mathrm{M} / \mathrm{D}$ structures was measured at room temperature, using a four-point technique.

The optical measurements were carried out at room temperature using a UV/visible spectrometer (PERKIN ELMER Lambda 1050 spectrophotometer). The optical transmission could be measured in $300 \mathrm{~nm}-2500 \mathrm{~nm}$ spectral range.

AFM images of the films were taken ex-situ at atmospheric pressure and room temperature. For each sample, the surface image was carried out in various places with a maximum scan size of $2 \times 2 \mu \mathrm{m}^{2}$. All measurements have been performed in tapping mode (Nanoscope IIIa, (Veeco, Inc.). Classical silicon cantilevers were used ( $\mathrm{NCH}$, nanosensors). The average force constant and resonance were approximately $40 \mathrm{~N} / \mathrm{m}$ and $300 \mathrm{kHz}$, respectively. The cantilever was excited at its resonance frequency. The AFM image processing was done using the Gwyddion V2.36 program which allows, calculation of the roughness of the surface (RMS).

The scotch tape method [46] was used to estimate the adhesion of the structures to the substrate. This test is only qualitative but it allows screening films involving poor adhesion from those where adhesion is good. The tape was pressed onto the film and then it was rapidly stripped. Three possibilities arise: (a) the film is completely removed from the substrate (b) the film is not at all removed, and (c) the film is partly removed.

Profiles of the multilayer structures films were examined using XPS technique. The relative quantitative study was based on the determination of the peak areas of the elements considered and their relative sensitivity factors (RSF) given by the constructor.

The flexibility of the W/A/W structures was studied using a laboratory made bending test system (Inset Figure 6). The samples were clamped between two parallel plates. One plate was mounted to the shaft of the motor, the other was fixed to a fixed support. The distance between the plates in the stretched mode was $25 \mathrm{~mm}$. The bending radius was around $6 \mathrm{~mm}$ and the bending frequency was $1 \mathrm{~Hz}$. During the bending test, the resistance of the samples was measured by a multimeter.

\subsection{Realization and characterization of devices using $D / M / D$ multilayer electrodes.}

To test the potential of the D/M/D multilayer structures as electrodes in the OPVCs we have made OPVCs using the planar heterojunction geometry. To this end, we used a structure that we have probed in the past, namely [47]:

Glass (PET) substrate/transparent anode $/ \mathrm{MO}_{3} / \mathrm{CuI} / \mathrm{CuPc} / \mathrm{C}_{60} / \mathrm{Alq}_{3} / \mathrm{Al}$ (Figure 2).

In these structures, the couple $\mathrm{MO}_{3} / \mathrm{CuI}$ is the hybrid hole transporting layer (HTL), $\mathrm{MO}_{3}$ corresponding to $\mathrm{MoO}_{3}$ or $\mathrm{WO}_{3}$. $\mathrm{Alq}_{3}$ is the exciton blocking layer (EBL), Al the anode, while $\mathrm{CuPc}$ is the electron donor and $\mathrm{C}_{60}$ is the electron acceptor of the planar heterojunction of the OPVC.

In these structures, the couple $\mathrm{MO}_{3} / \mathrm{CuI}$ is the hybrid hole transporting layer (HTL), $\mathrm{MO}_{3}$ corresponding to $\mathrm{MoO}_{3}$ or $\mathrm{WO}_{3} . \mathrm{Alq}_{3}$ is the exciton blocking layer (EBL), Al the anode, while $\mathrm{CuPc}$ is the electron donor and $\mathrm{C}_{60}$ is the electron acceptor of the planar heterojunction 
of the OPVC. With regard to the anode, we used our D/M/D multilayer structures, and also ITO anode as reference OPVCs. The ITO thin film was $100 \mathrm{~nm}$ thick and its sheet resistance was $20 \Omega /$ sq, in the case of glass substrates, and $100 \Omega /$ sq in the case of PET substrates.

The electrical characterization of the OPVCs was performed with an I-V tester, in the dark and under sun global AM 1.5 simulated solar illumination.

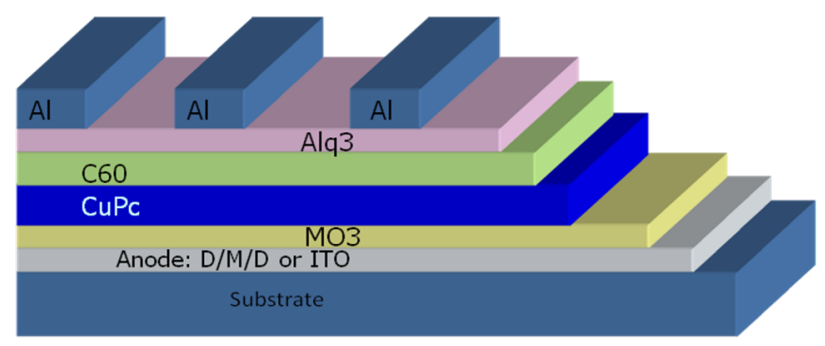

Figure 2: Typical scheme of a planar heterojunction solar cell.

In these structures, the couple $\mathrm{MO}_{3} / \mathrm{CuI}$ is the hybrid hole transporting layer (HTL), $\mathrm{MO}_{3}$ corresponding to $\mathrm{MoO}_{3}$ or $\mathrm{WO}_{3}$. Alq ${ }_{3}$ is the exciton blocking layer (EBL), Al the anode, while $\mathrm{CuPc}$ is the electron donor and $\mathrm{C}_{60}$ is the electron acceptor of the planar heterojunction of the OPVC. With regard to the anode, we used our D/M/D multilayer structures, and also ITO anode as reference OPVCs. The ITO thin film was $100 \mathrm{~nm}$ thick and its sheet resistance was $20 \Omega /$ sq, in the case of glass substrates, and $100 \Omega /$ sq in the case of PET substrates.

The electrical characterization of the OPVCs was performed with an I-V tester, in the dark and under sun global AM 1.5 simulated solar illumination.

\section{RESULTS and DISCUSSION}

\subsection{D/Ag/D multilayer characterization and uses}

The dielectrics used were two transition metal oxides, $\mathrm{MoO}_{3}$ and $\mathrm{WO}_{3}$, which were proved to be efficient HTL in OPVCs. About the metal, Ag was first used because it is known to give performing $\mathrm{D} / \mathrm{Ag} / \mathrm{D}$ structures due to its high conductivity and low absorptivity in the visible [48-50]. Nevertheless, $\mathrm{Ag}$ being quite expensive, then we tried to substitute $\mathrm{Cu}$ to $\mathrm{Ag}$. $\mathrm{Cu}$ is far less expensive than $\mathrm{Ag}$ (100 times), however, the properties of $\mathrm{D} / \mathrm{Cu} / \mathrm{D}$ structures are far less stables than that of $\mathrm{D} / \mathrm{Ag} / \mathrm{D}$ structures [51]. So we had to use $\mathrm{Cu}$ alloys to improve the stability of the structures, these alloys were $\mathrm{Cu}: \mathrm{Ni}$ and $\mathrm{Cu}: \mathrm{Al}$.

3.1.1 $\mathrm{MO}_{3} / \mathrm{Ag} / \mathrm{MO}_{3}$ structures, with $\mathrm{MO}_{3}=\mathrm{MoO}_{3}$ or $\mathrm{WO}_{3}$.

Firstly we worked on $\mathrm{MoO}_{3} / \mathrm{Ag} / \mathrm{MoO}_{3}$ structures. These structures being to be used as TCE, the first characterizations to which they were subjected were measure of their optical and electrical properties. From these measures, in order to compare the performances of different electrodes et to determinate the best compromise "Conductivit-transmission », we calculate the figure of merit $\left(\Phi_{M}\right)$ proposed by Haack using the empiric formulae [52]:

$$
\Phi_{\mathrm{M}}=\mathrm{T}^{10} / \sigma_{\text {sh }} \text {. }
$$

$\mathrm{T}$ transmission and $\sigma_{\mathrm{sh}}$ sheet resistance,

Thanks to this formula it is possible to compare the "opto-electric » performances of the different electrodes.

Before starting experiments, in order to estimate roughly the optimal thicknesses it is helpful to proceed to numerical optimization of the multilayer electrode in order to have an order of magnitude of the thickness of the different layers [53].

Following the studies made in various laboratories, some general rules can be set out. 
For instance, the intercalation of an oxide layer between the substrate and the metal layer allows increasing significantly the transmission of light. For instance, the averaged transmission of a structure Glass $/ \mathrm{MoO}_{3}(35 \mathrm{~nm}) / \mathrm{Ag}(10 \mathrm{~nm}) / \mathrm{MoO}_{3}(20 \mathrm{~nm})$ between 400 and $700 \mathrm{~nm}$ is $75 \%$, while that of a structure Glass/Ag $(10 \mathrm{~nm}) / \mathrm{MoO}_{3}(20 \mathrm{~nm})$ and is only $55 \%$, which shows that the bottom oxide layer in $\mathrm{D} / \mathrm{M} / \mathrm{D}$ structure is determinant for achieving high transmission of the electrodes. This result corroborates the theoretical calculations [53].

Whatever the oxide, there is a red shift of the transmission spectrum when the thickness of the top oxide layer increases [54]. It must be noted that this red shift is accompanied by a widening of the transmission range. This effect tends to saturate when the top $\mathrm{MoO}_{3}$ layer thickness overpasses $20 \mathrm{~nm}$. Therefore, we chose that thickness for this top layer, while the optimum thickness of the bottom $\mathrm{MoO}_{3}$ layer was estimated to be $35 \mathrm{~nm}$ [54].

After studying the influence of the thickness of the oxide layers on the device performances, we proceeded to the study of the effect of the silver layer thickness. Typical results are shown in Figure 3.

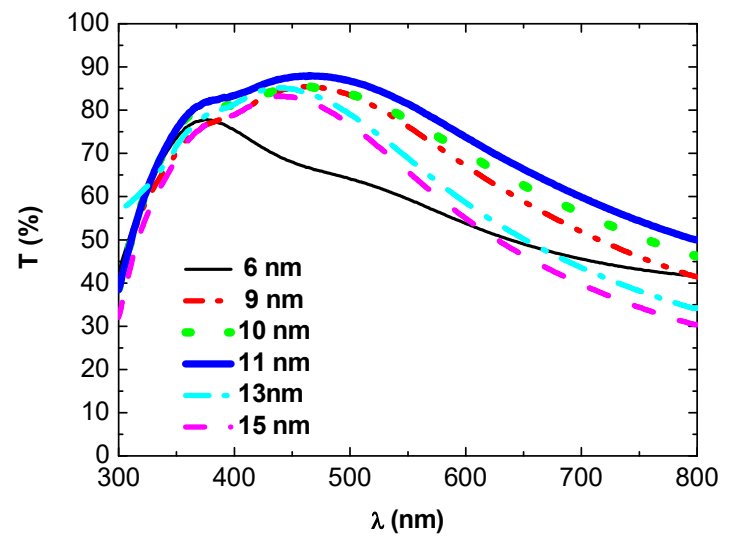

Figure 3: Transmission spectra of glass $/ \mathrm{MoO}_{3}(35 \mathrm{~nm}) / \mathrm{Ag}(\mathrm{Y} \mathrm{nm}) / \mathrm{MoO}_{3}(20 \mathrm{~nm})$ structures with $\mathrm{Y}$ ranging between $6 \mathrm{~nm}$ and $15 \mathrm{~nm}$.

The transmission of the light increases with the Ag layer thickness up to an optimum value, here $11 \mathrm{~nm}$, beyond this thickness the light transmission starts to decrease. This behaviour, which is classical for such $\mathrm{D} / \mathrm{M} / \mathrm{D}$ structures, can be explained as follow. Below the optimum thickness value, the Ag layer is not continuous (Figure 4a).
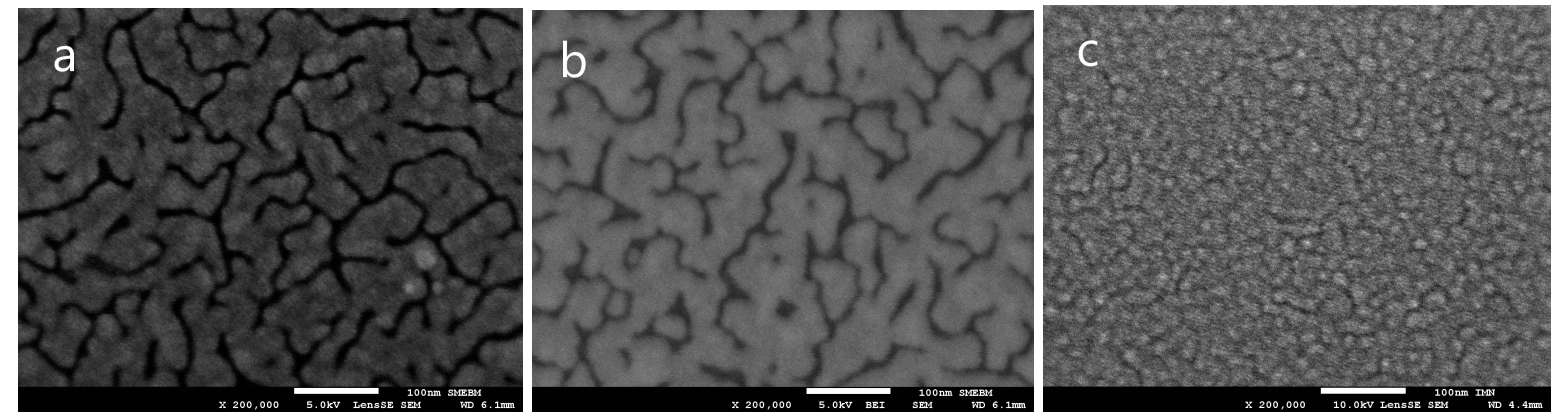

Figure 4: $\mathrm{SEM}$ images of the surface of glass $/ \mathrm{MoO}_{3}(35 \mathrm{~nm}) / \mathrm{Ag}(\mathrm{X} \mathrm{nm})$ structures, with an $\mathrm{Ag}$ layer thickness of $9 \mathrm{~nm}(\mathrm{a})$ in the secondary electron mode, (b) in the backscattering mode and (c) with an Ag thickness of $11 \mathrm{~nm}$. 
The black paths visible on the surface of a substrate/ $\mathrm{MoO}_{3} / \mathrm{Ag}$ structure correspond to the glass substrates as attested by the Figure $4 \mathrm{~b}$. Actually, the photograph of Figure $4 \mathrm{~b}$ has been obtained using the back-scattering mode, which means that the white region of the photography corresponds to the heavier atoms, here Ag, while the black region to the lighter molecule $\left(\mathrm{SiO}_{2}\right)$. Therefore, the films consist in silver aggregates which induces some light diffusion, which decreases the light transmission.

When the thickness increases up to a critical value, there is percolation of the Ag layer and the films become homogeneous (Figure 4c). Here, it must be noted that the threshold value of the thickness depends on the deposition rate of the silver film [55]. It decreases when the deposition rate increases. It is $10 \mathrm{~nm}$ for a deposition rate of $0.3 \mathrm{~nm} / \mathrm{s}$ and $12 \mathrm{~nm}$ for a deposition rate of $0.1 \mathrm{~nm} / \mathrm{s}$. At the percolation, the $\mathrm{Ag}$ film becomes homogeneous, the light diffusion disappears with the in homogeneities of the films and the transmission is maximum. Beyond the thickness corresponding to the percolation value, the transmission decreases because of the absorption and reflection of the Ag layer, which increase with the thickness of the metal layer.

Since the optimum transmission spectrum is obtained at the percolation of the Ag film, it corresponds to threshold of the conductivity of the multilayer structures from an insulating state to a conductive state. Beyond this thickness, the sheet resistance of the structures decreases slowly (Table 1).

Table 1: variation of the sheet resistance and transmission of $\mathrm{MoO}_{3} / \mathrm{Ag} / \mathrm{MoO}_{3}$ structures with the Ag layer thickness.

\begin{tabular}{ccccccccc}
\hline Ag thickness $(\mathrm{nm})$ & 6 & 9 & 10 & 11 & 12 & 13 & 14 & 15 \\
\hline Sheet resistance $(\Omega / \mathrm{sq})$ & $5 \times 10^{6}$ & $1 \times 10^{6}$ & 25 & 15 & 10 & 9 & 8.5 & 8.5 \\
$\mathrm{~T}_{\text {Max }(\%)}$ & 77.6 & 85.4 & 85.5 & 87.9 & 85.2 & 84.2 & 83.7 & 82.5 \\
$10^{3} \times \Phi_{\mathrm{M}}\left(\Omega^{-1}\right)$ & - & - & 8.3 & 18.3 & 20.1 & 19.9 & 19.8 & 17.2 \\
\hline
\end{tabular}

From table 1, the optimum structure is obtained with $12 \mathrm{~nm}$ of silver. For comparison the figure of merit of ITO used in the laboratry is $15.4 \times 10^{-3} \Omega^{-1}$ when deposited on glass and $5.4 \times 10^{-3} \Omega^{-1}$ when deposited onto PET [56]. It can be concluded that optimum compromise between optical and electrical properties of the $\mathrm{D} / \mathrm{Ag} / \mathrm{D}$ structures is similar to that of ITO.

After verifying that it is possible to achieve transparent conductive electrode using $\mathrm{D} / \mathrm{Ag} / \mathrm{D}$ structures, we proceeded to some more specific characterizations. It is known that it is necessary to use very smooth electrode in organic devices to avoid leakage current, the organic layer thickness being very small.

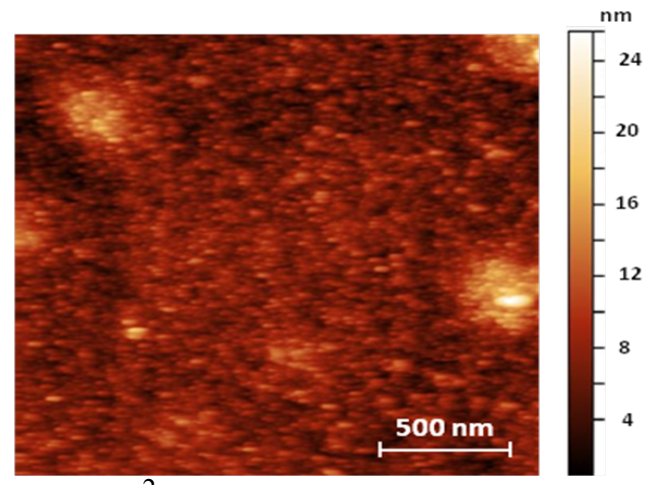

Figure 5: AFM image $\left(2 \times 2 \mu \mathrm{m}^{2}\right)$ of a glass $/ \mathrm{MoO}_{3}(35 \mathrm{~nm}) / \mathrm{Ag}(11 \mathrm{~nm}) / \mathrm{MoO}_{3}(20 \mathrm{~nm})$ structures. 
The morphology of the multilayer after complete realization is highly homogenous, a typical AFM image of a $\mathrm{MoO}_{3} / \mathrm{Ag} / \mathrm{MoO}_{3}$ structure is shown in Figure 5. It can be seen that the structures are highly homogeneous with a RMS around $1.7 \mathrm{~nm}$ which is small while the maximum peak to valley value is $24 \mathrm{~nm}$.

Some structures were deposited onto PET. After checking that here also transparent and conductive electrodes can be obtained, see table 2, their flexibility was verified. A typical result is reported in figure 6 . Whatever the bending process, outer or inner, the variation of the sheet resistant is negligible in the case of $\mathrm{D} / \mathrm{Ag} / \mathrm{D}$ structure, while it is not in the case of ITO.

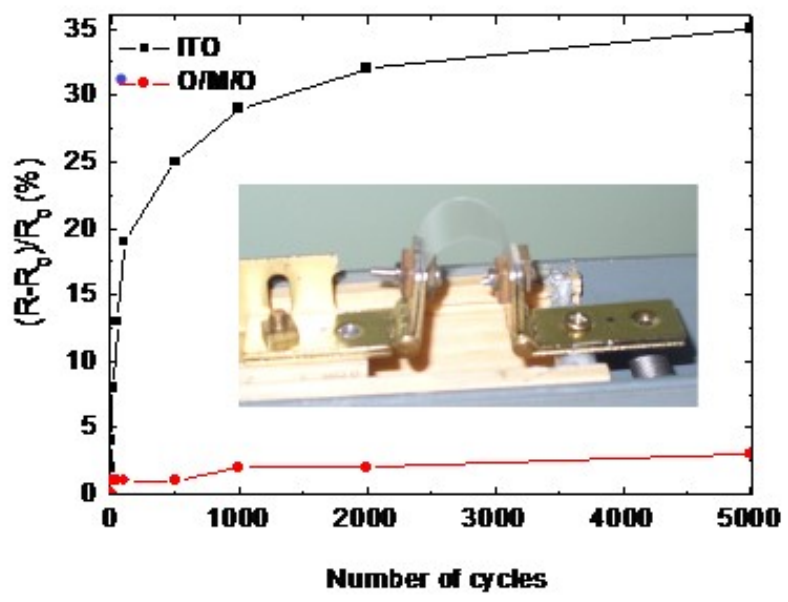

Figure 6: Resistance evolution after bending as a function of the number of bending cycles for PET/MoO $3 / \mathrm{Ag} / \mathrm{MoO}_{3}(\bullet)$ and PET/ITO (ロ) structures.

The adhesion of the $\mathrm{MoO}_{3} / \mathrm{Ag} / \mathrm{MoO}_{3}$ structure deposited onto glass or PET was checked by the "scotch tape test". Not only the $\mathrm{MoO}_{3} / \mathrm{Ag} / \mathrm{MoO}_{3}$ structure resist perfectly to this adhesion test since the film is not at all removed, but the sheet resistance of these structures did not increase after the test. We have also measured more precisely the mechanical properties and the adhesion of the $\mathrm{MoO}_{3} / \mathrm{Ag} / \mathrm{MoO}_{3}$ structure to the substrates [46] Using a scratching test apparartus, we have shown that, if the $\mathrm{MoO}_{3} / \mathrm{Ag} / \mathrm{MoO}_{3}$ structures exhibit a good adhesion to the substrates, this adhesion is not as high as that of ITO. Nevertheless, these experiments show also that the $\mathrm{MoO}_{3} / \mathrm{Ag} / \mathrm{MoO}_{3}$ structures are less brittle than ITO, which was expected.

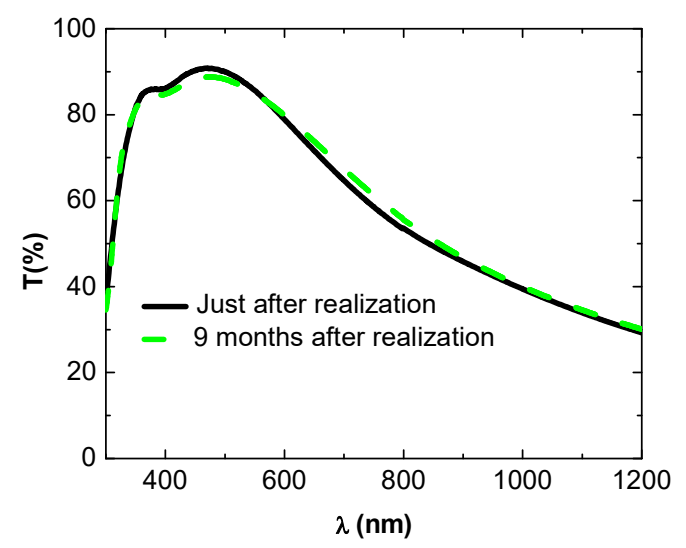

Figure 7: Transmission spectra of a $\mathrm{MoO}_{3} / \mathrm{Ag} / \mathrm{MoO}_{3}$ structure just after realization and 9 months after. 
We have also probed the lifetime of the structures [57]. The structures were stored in room air. Firstly, it can be in Figure 7 that, after 9 months there is not a great modification of the transmission spectrum. In fact, there is a small increase (around 1\%) of the averaged transmission. Such increase is due to the fact just after deposition, the $\mathrm{MoO}_{3}$ layers are oxygen deficient, which induces a light blue color to the structures. With time, while the oxygen deficiency decreases, this color tends to progressively disappears,

About the long-term study on the evolution of the conductivity. The study described in Ref. [57] shows that the conductivity varies significantly from one sample to another one. More precisely we have shown that the lifetime of the $\mathrm{D} / \mathrm{Ag} / \mathrm{D}$ structures depends significantly on the cleanliness of their substrates. When the substrates were clean, five years old $\mathrm{MoO}_{3} / \mathrm{Ag} / \mathrm{MoO}_{3}$ structures are still transparent, conductive and homogeneous. When the samples are not so clean, inhomogeneities grow around microscopic particles, dusts, pinholes... When we analysed these inhomogeneities, it was shown that they were silver rich. This shows that there is Ag migration from the non-disturbed domains towards the disturbed one. When the density of inhomogeneities is high enough, the Ag migration allowing the formation of these inhomogeneities does that the Ag layer is not continuous anymore, which makes that the $\mathrm{MoO}_{3} / \mathrm{Ag} / \mathrm{MoO}_{3}$ structures become insulating. Following study of Ross [58], it is supposed that the initiation of $\mathrm{Ag}$ diffusion, involves $\mathrm{H}_{2} \mathrm{O}$ contact with the $\mathrm{Ag}$ layer through a breach in the over coating oxide film. Then the perturbation grows progressively inducing formation of metal depleted zones and finally loss of conductivity of the structures. Therefore great care must be taken for the cleaning of the substrates and the storing conditions of the $\mathrm{MoO}_{3} / \mathrm{Ag} / \mathrm{MoO}_{3}$ structures.

Since we have shown that the density of $\mathrm{WO}_{3}$ thin films deposited by sublimation under vacuum is higher than that of $\mathrm{MoO}_{3}$, which permits to oppose better the diffusion of the atoms of metals, we have also worked on $\mathrm{WO}_{3} / \mathrm{M} / \mathrm{WO}_{3}$ structures [59, 60]. Actually, after optimisation of the $\mathrm{Ag}$ layer thickness, the best structures using $\mathrm{WO}_{3}$ in place of $\mathrm{MoO}_{3}$ exhibit the following performances: sheet resistance $(8 \Omega / \mathrm{sq})$, high transmission in the visible $\left(\mathrm{T}_{\mathrm{Max}}=91.5 \%\right.$, averaged $\left.\mathrm{T} 400-700=80.6 \%\right)$ and an optimum averaged figure of merit $\Phi_{\mathrm{TC}}=27$ $10^{-3} \Omega^{-1}$ for the structure $\mathrm{WO}_{3}(35 \mathrm{~nm}) / \mathrm{Ag}(16 \mathrm{~nm}) / \mathrm{WO}_{3}(20 \mathrm{~nm})$.

Finally, we have used the D/Ag/D structures in different devices. For instance, since the $\mathrm{WO}_{3} / \mathrm{Ag} / \mathrm{WO}_{3}$ structures present high transmittance in the visible and high reflection in the near infrared and infrared regions, they have been probed as transparent heat mirror (THM).
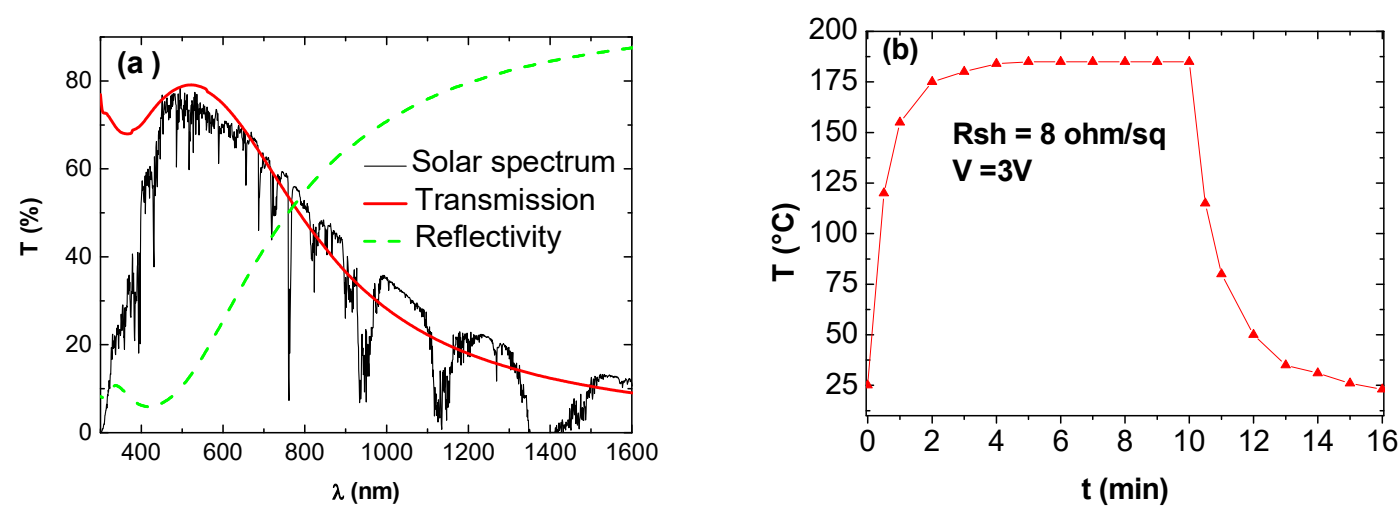

Figure 8: (a)Transmission (-) and reflectivity (----) of Glass $/ \mathrm{WO}_{3} / \mathrm{Ag} / \mathrm{WO}_{3}$ multilayer structures and representation of the solar spectrum (AM1.5) and (b) Temperature variation with time at a constant applied voltage of $3 \mathrm{~V}$, the sheet resistance of the $\mathrm{WO}_{3} / \mathrm{Ag} / \mathrm{WO}_{3}$ structures being $8 \Omega / \mathrm{sq}$. 
A THM must transmit in the visible range and reflects in the near-infrared (NIR) and infrared (IR) range, which is the case of the $\mathrm{WO}_{3} / \mathrm{Ag} / \mathrm{WO}_{3}$ structures as shown in Figure 8a. It can be seen that it transmits the largest part of the visible spectre while it reflects the solar spectrum in the IR. Such THM can be used in energy efficient windows [61, 62].

They can also be used as transparent heater (TH). THs are transparent and electrically conducting thin films which are used for the conversion of electrical energy into thermal energy [63]. To test the $\mathrm{WO}_{3} / \mathrm{Ag} / \mathrm{WO}_{3}$ structures two aluminium electrodes, spaced $1 \mathrm{~cm}$ apart, were deposited, while he temperature measurements were taken via copper/constantan thermocouples. For samples with Rsh $=8 \Omega /$ sq the Figure $8 \mathrm{~b}$ shows that when a constant voltage of $3 \mathrm{~V}$ is applied the heating and cooling rates are $2.2{ }^{\circ} \mathrm{C}$ per second and $-1.2{ }^{\circ} \mathrm{C}$ respectively. These performances are of the same order of than those obtained with AgNWs for instance, which makes that these THs can be used as window defroster and outdoor panel display.

However the most important results were obtained when we use these structures as anode in OPVCs. It was shown that, before the deposition of the different layers constituting the OPVCs, it is necessary to proceed to the deposition of an HTL to obtain OPVCs efficiencies of the same order of magnitude than that obtained with ITO for the same organic heterojunction. The HTL used was CuI since we have already shown that it very efficient when $\mathrm{CuPc}$ is the ED [55]. An example is given in Figure 9 and table 2.

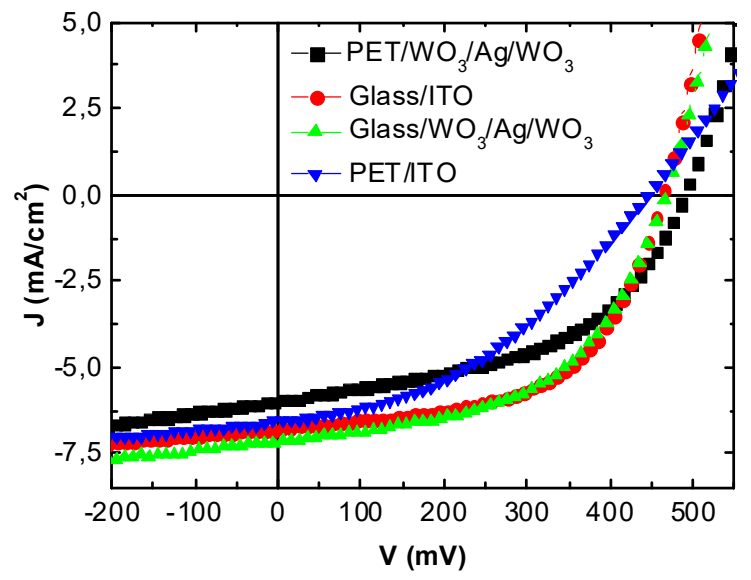

Figure 9: $\mathrm{J}-\mathrm{V}$ characteristics of OPVCs with Glass/ITO $(\bullet)$, Glass/ $\mathrm{W0}_{3} / \mathrm{Ag} / \mathrm{WO}_{3}(\Delta)$, $\mathrm{PET} / \mathrm{ITO}(\boldsymbol{\nabla})$ and $\mathrm{PET} / \mathrm{W0}_{3} / \mathrm{Ag} / \mathrm{WO}_{3}(\boldsymbol{\square})$ as anode.

Table 2: Parameters of OPVCs with different anodes.

\begin{tabular}{ccccc}
\hline Anode & Voc $(\mathrm{V})$ & $\mathrm{Jsc}\left(\mathrm{mA} / \mathrm{cm}^{2}\right)$ & $\mathrm{FF}(\%)$ & $\eta(\%)$ \\
\hline Glass $/ \mathrm{W0}_{3} / \mathrm{Ag} / \mathrm{WO}_{3}$ & $\mathrm{O} .46$ & 7.17 & 53 & 1.75 \\
Glass $/ \mathrm{ITO}$ & 0.46 & 6.78 & 56 & 1.75 \\
$\mathrm{PET} / \mathrm{W} 0_{3} / \mathrm{Ag} / \mathrm{WO}_{3}$ & 0.48 & 6.10 & 49 & 1.42 \\
$\mathrm{PET} / \mathrm{ITO}$ & 0.45 & 6.57 & 40 & 1.17 \\
\hline
\end{tabular}

Therefore it can be concluded $\mathrm{D} / \mathrm{Ag} / \mathrm{D}$ structures present Figure of merit of the same order of magnitude than those obtained with ITO, which makes that the OPVCs achieved with these $\mathrm{D} / \mathrm{Ag} / \mathrm{D}$ transparent conductive electrodes exhibit the same efficiency than that obtained with ITO and even better performances in the case of PET substrates. Moreover, in the case of PET substrates, when the OPVCs are submitted to bending tests, the degradation of the 
performances is faster in the case of ITO. After 5 cycles, the efficiency relative losses is only $3 \%$ in the case of $\mathrm{WO}_{3} / \mathrm{Ag} / \mathrm{WO}_{3}$ structure, while it is $15 \%$ in the case of ITO.

\subsection{D/Ag/D multilayer characterization and uses}

Nevertheless, if these $\mathrm{D} / \mathrm{Ag} / \mathrm{D}$ multilayer structures are highly performing, the presence of $\mathrm{Ag}$ is a brake in its industrial use because of the relatively high cost of the Ag. Therefore, the conductivity of $\mathrm{Cu}$ being nearly as high as that of $\mathrm{Ag}$, we have tried to substitute $\mathrm{Cu}$ to $\mathrm{Ag}$. Moreover, the wavelength corresponding to the maximum of transmission is different for $\mathrm{Ag}(\lambda=460 \mathrm{~nm})$ and $\mathrm{Cu}(\lambda=590 \mathrm{~nm})$, which should allows to induce a red shift of the transmission range when $\mathrm{Cu}$ is substituted to $\mathrm{Ag}$. Unfortunately, $\mathrm{Cu}$ ions diffuse massively into $\mathrm{MoO}_{3}$, which makes that it was necessary to introduce two $\mathrm{Al}$ barrier layers to limit $\mathrm{Cu}$ diffusion [51].

Even if $\mathrm{Cu}$ diffusion into $\mathrm{WO}_{3}$ or, better, $\mathrm{ZnS}$, is smaller, the properties of multilayer structures using $\mathrm{Cu}$ as metal layer are not stable in the time. So, in order to improve the stability of the $\mathrm{D} / \mathrm{Cu} / \mathrm{D}$ structures we replace pur $\mathrm{Cu}$ with $\mathrm{Cu}$ Alloys. Due to the quality of $\mathrm{Ni}$ as barrier diffusion, we first probe $\mathrm{Cu}: \mathrm{Ni}$ alloys with a Ni concentration of $10 \mathrm{~W} . \%$.

The melting temperature of $\mathrm{Ni}$ and $\mathrm{Cu}$ being different, we had to use a high deposition rate $(0.6 \mathrm{~nm} / \mathrm{s})$ to be sure to introduce some $\mathrm{Ni}$ in the $\mathrm{Cu}$ film.

Immediately after deposition of these structures exhibit behaviors similar to that of $\mathrm{D} / \mathrm{Ag} / \mathrm{D}$ structures. The transmission increases with the thickness of the $\mathrm{Cu}$ layer up to the percolation and then decreases. At the percolation the conductivity of the structure commutes from an insulating state (before percolation) to a conductive state (after percolation). The variations of the properties of the structures with the $\mathrm{Cu}$ :Ni layer thickness are summarized in Table 3.

Table 3: Sheet resistance (and its variation with time), Averaged Transmission, Figure of Merit of $\mathrm{WO}_{3} / \mathrm{Cu}: \mathrm{Ni} / \mathrm{WO}_{3}$ structures, with different metal layer thicknesses.

\begin{tabular}{ccccc}
\hline Cu:Nithickness $(\mathrm{nm})$ & $\mathrm{Rsh}(\Omega / \mathrm{sq})$ & $\mathrm{T}_{\mathrm{Max}}(\%)$ & $\Phi_{\mathrm{M}} \times 10^{-3}(\Omega)^{-1}$ & $\begin{array}{c}\text { Rsh }(\Omega / \mathrm{sq}) \\
\text { 9 months latter }\end{array}$ \\
\hline 8 & 60 & 68 & 0.3 & \\
10 & 29 & 73 & 1.5 & 180 \\
12 & 7.5 & 80 & 14.5 & 9.4 \\
14 & 6 & 69 & 4 & \\
16 & 6 & 65 & 2.2 & \\
\hline
\end{tabular}

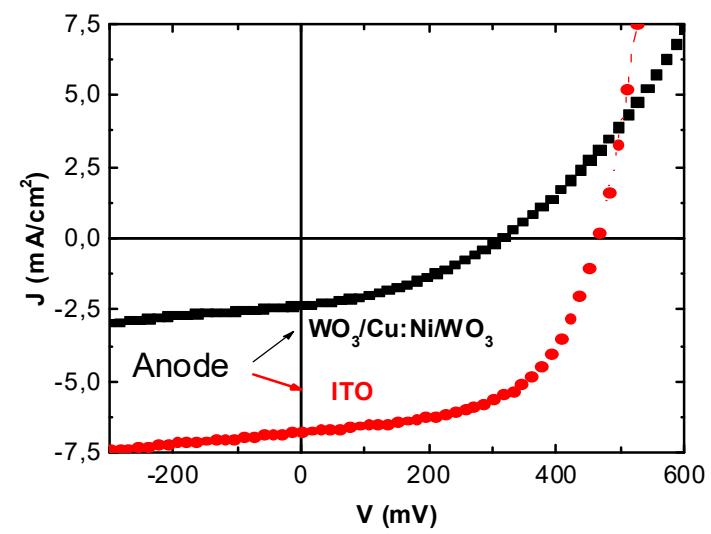

Figure 10: J-V characteristics of OPVCs with ITO $(\bullet)$ and $\mathrm{WO}_{3} / \mathrm{Cu}: \mathrm{Ni} / \mathrm{WO}_{3}(\boldsymbol{\bullet})$ as anode. 
It can be seen that, if the percolation occurs for a thickness of $12 \mathrm{~nm}$ of $\mathrm{Cu}: \mathrm{Ni}$, the electrical properties of the structures are not stable, which makes that it is necessary to use structures with $14 \mathrm{~nm}$ of $\mathrm{Cu}: \mathrm{Ni}$ to obtain electrodes with relatively stable properties.

Of course such increase in the metal layer thickness induces some decrease of the transmission and therefore of the Figure of Merit of the structure. Moreover, when used as electrode in OPVCs, the results are disappointing. Actually, the Voc and FF values are far smaller than those obtained with ITO (Figure 10),

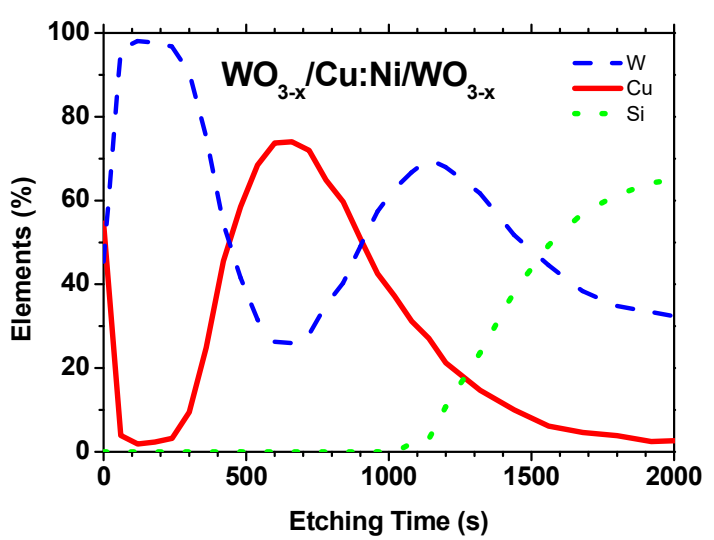

Figure 11: $\mathrm{XPS}$ profile of $\mathrm{Cu}$ and $\mathrm{W}$ in $\mathrm{WO}_{3-\mathrm{x}} / \mathrm{Cu}: \mathrm{Ni} / \mathrm{WO}_{3-\mathrm{x}}$ structures

In order to understand this result we proceeded to the study of the repartition of $\mathrm{Cu}$ in the structure. The XPS profile in figure 11 shows that if there is, as expected, a $\mathrm{Cu}$ layer in the centre of the structure, there is also a high atomic percentage of $\mathrm{Cu}$ on the surface of the structure. This very thin layer of $\mathrm{Cu}$ contaminates the interface anode/organic material, which makes that the OPVCs efficiency is very small.

In fact, the stabilisation of $\mathrm{Cu}$ is limited by the fact that, using a simple evaporation technique for the deposition of the alloy, we cannot introduce more than 0.5 at. $\%$ of $\mathrm{Ni}$ into the $\mathrm{Cu}$. Therefore we choose another metal, $\mathrm{Al}$, whose melting point is closer to that of $\mathrm{Cu}$, so we can vary the composition.

The starting alloy was $\mathrm{Cu}: \mathrm{Al} 6 \mathrm{w} . \%$ and the composition of the metal films depends on the deposition rate of the alloy. The atomic concentration of $\mathrm{Al}$ in the deposited alloy films was $1.5,2,3$ and 5 at.\% for deposition rates of $0.3,0.6,0.8$ and $1 \mathrm{~nm} / \mathrm{s}$. The films deposited at $0.3 \mathrm{~nm} / \mathrm{s}$ were grey and insulating, while those deposited at rate equal or faster than $0.6 \mathrm{~nm} / \mathrm{s}$ were pink and conductive. It means that, at least, $2 \%$ of $\mathrm{Al}$ are necessary to stabilize the structures. On the other hand, an $\mathrm{Al}$ concentration higher than 3\% induces losses on the transparency and conductivity of the $\mathrm{WO}_{3} / \mathrm{Cu}: \mathrm{Al} / \mathrm{WO}_{3}$ structures. Therefore, we used to deposit the alloy at a deposition rate of $0.6 \mathrm{~nm} / \mathrm{s}$. If the structures deposited at this deposition rate were pink and conductive, their properties tended to degrade in a few days. It is why we decided to introduce a thin $\mathrm{Ag}$ layer onto the bottom $\mathrm{WO}_{3}$ layer before $\mathrm{Cu}$ :Al deposition. Actually, a single nanometer was enough for improving significantly the stability of the structures. However, for more stability we have decided to deposit $2 \mathrm{~nm}$ of Ag. Then we have optimized the $\mathrm{Cu}$ :Al thickness. The best result are obtained for $14 \mathrm{~nm}-15 \mathrm{~nm}$ of $\mathrm{Cu}: \mathrm{Al}$, with Tmax $=82 \%$. It means that, for these thicknesses, there is percolation of the alloy layer. For thinner films the sheet resistance increases rapidly and the light transmission decreases. IT is due to the heterogeneities-discontinuity of the metal layer which induces some light diffusion. For films thicker than $15 \mathrm{~nm}$, the reflectivity of the metal layer increases and the transmission decreases. These structures are smooth $(\mathrm{RMS}=2 \mathrm{~nm})$ and flexible.

The evolution of the sheet resistance of the structures $\mathrm{WO}_{3}(35 \mathrm{~nm}) / \mathrm{Ag}(2 \mathrm{~nm}) / \mathrm{Cu}: \mathrm{Al}$ $\mathrm{x}$ at. $\%(14.5 \mathrm{~nm}) / \mathrm{WO}_{3}(20 \mathrm{~nm})$ with $\mathrm{x}=1$ or 3 is reported in table 4 . It can be seen that, while 
Rsh of the structure with 1at.\% of $\mathrm{Al}$ increases continuously, that of structure containing 3 at.\% of $\mathrm{Al}$ tends to saturate at a maximum acceptable value of $80 \Omega / \mathrm{sq}$. It can be concluded that the intercalation of $2 \mathrm{~nm}$ of $\mathrm{Ag}$ between $\mathrm{WO}_{3}$ and $\mathrm{Cu}$ :Al with $\mathrm{x}=3$ at.\%, improves significantly the stability of the structure.

Table 4: Evolution with time of the sheet resistance of $\mathrm{WO}_{3}(35 \mathrm{~nm}) / \mathrm{Ag}(2 \mathrm{~nm}) / \mathrm{Cu}: \mathrm{Al}(14$ $\mathrm{nm})(14.5 \mathrm{~nm}) / \mathrm{WO}_{3}(20 \mathrm{~nm})$ structures with 1 at $\%$ and 3 at.\% of $\mathrm{Al}$ in the metal alloy.

\begin{tabular}{cccccccccc}
\hline Time (Days) & 0 & 1 & 5 & 9 & 13 & 17 & 24 & 55 & 110 \\
\hline \multicolumn{8}{c}{ Sheet resistance $(\Omega / \mathrm{sq})$} \\
\hline $\mathrm{Ag} / \mathrm{Cu}: \mathrm{Al} 1$ at. $\%$ & 30 & 31 & 33 & 39 & 45 & 60 & 83 & 150 & 224 \\
$\mathrm{Ag} / \mathrm{Cu}: \mathrm{Al} 3$ at. $\%$ & 25 & 26 & 30 & 37 & 42 & 52 & 60 & 76 & 80 \\
\hline
\end{tabular}

Therefore, $2 \mathrm{~nm}$ of $\mathrm{Ag}$ seems to be an efficient barrier to prevent $\mathrm{Cu}$ diffusion. In fact, we have checked the repartition of $\mathrm{Ag}$ and $\mathrm{Cu}$ along the whole thickness of the structure thanks to XPS depth profiles and it can be seen in Figure 12 that Ag does not behave as a barrier, but it diffuses all along the copper layer, which stabilizes the $\mathrm{Cu}$ layer at the centre of the structure.

Actually Ag and $\mathrm{Cu}$ have large miscibility, which may possible the formation of the $\mathrm{Cu}: \mathrm{Al}: \mathrm{Ag}$ alloy. It was already shown that the presence of $\mathrm{Cu}$ in $\mathrm{Ag}$ or vice-versa, improves the stability $\mathrm{O} / \mathrm{Ag}: \mathrm{Cu} / \mathrm{O}$ structures [64].

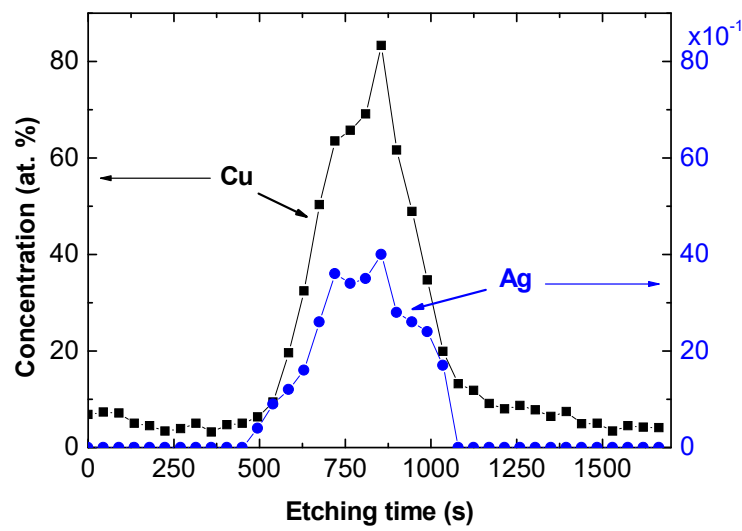

Figure 12: XPS profile of $\mathrm{Cu} 2 \mathrm{p}$ and $\mathrm{Ag} 3 \mathrm{~d}$ in $\mathrm{WO}_{3-\mathrm{x}} / \mathrm{Ag} / \mathrm{Cu}: \mathrm{Al} / \mathrm{WO}_{3-\mathrm{x}}$ structures

About the $\mathrm{Al}$ present in the alloy, it should be oxidized. This $\mathrm{Al}_{2} \mathrm{O}_{3}$ must act as pinning at the grain boundaries and limits the $\mathrm{Cu}$ atomic motion. So, it enhances the structure stability [65]. After these characterizations we have introduced these new electrodes in "substrate/transparent anode $/ \mathrm{MO}_{3} / \mathrm{CuI} / \mathrm{ED} / \mathrm{C}_{60} / \mathrm{Alq}_{3} / \mathrm{Al}$ " OPVCs

The J-V characteristics obtained are reported Figure 13 and summarized in Table 5.We can notice that the results, Table 5 , are better than those obtained with the $\mathrm{Cu} / \mathrm{Ni}$ alloy. It is probably due to the fact that, if some $\mathrm{Cu}$ is still present at the surface of the electrode, its concentration is far smaller. Nevertheless, if the efficiency is of the same order than that obtained with ITO, it stays slightly smaller. However it is interesting to note that for cells deposited onto PET, when they are submitted to a bending stress, the relative degradation of their performances is smaller $(2 \%)$ than in the case of ITO/PET ( $8 \%)$. 


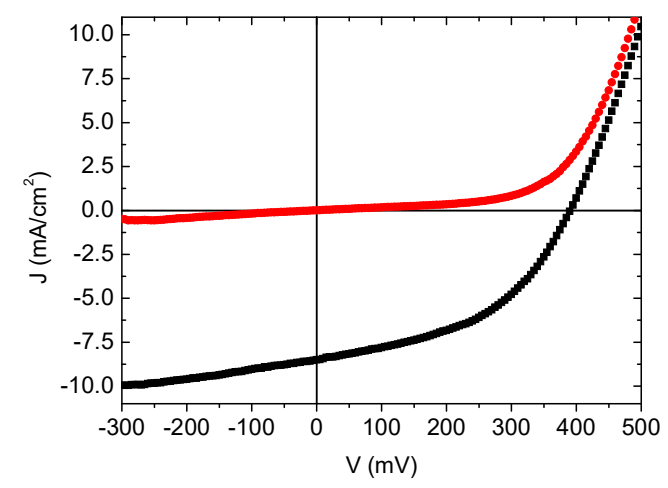

Figure 13: $\mathrm{J}-\mathrm{V}$ characteristics of an $\mathrm{OPVC}$ with $\mathrm{W}_{3} / \mathrm{Ag} / \mathrm{Cu}: \mathrm{Al} / \mathrm{WO}_{3}$ as anode, ( $\left.\mathbf{m}\right)$ under light and $(\bullet)$ in the obscurity.

Table 5: Comparison of the parameters of OPVCs with $\mathrm{WO}_{3} / \mathrm{Ag} / \mathrm{Cu}: \mathrm{Al} / \mathrm{WO}_{3}$ or ITO anodes.

\begin{tabular}{ccccc}
\hline Anode & Voc $(\mathrm{V})$ & $\mathrm{Jsc}\left(\mathrm{mA} / \mathrm{cm}^{2}\right)$ & $\mathrm{FF}(\%)$ & $\eta(\%)$ \\
\hline $\mathrm{WO}_{3} / \mathrm{Ag} / \mathrm{Cu}: \mathrm{Al} / \mathrm{WO}_{3}$ & 0.40 & 8.5 & 46 & 1.35 \\
$\mathrm{ITO}$ & 0.46 & 6.78 & 56 & 1.75 \\
\hline
\end{tabular}

As mentioned in the introduction, among the possible smart windows technologies, besides the THMs there are electrochromic (EC) windows that switch between transparent and opaque. The colour change for EC materials can be realized by reversible redox reaction under applied potentials. Transition metal oxides, such as $\mathrm{MoO}_{3}$ and $\mathrm{WO}_{3}$, are well known as efficient EC materials [66]. Therefore, in the present work, we have probed our D/Ag/D structures as electrode in EC windows.

The structures probed were as follow, an EC electrode $\mathrm{WO}_{3} / \mathrm{Ag} / \mathrm{Cu}: \mathrm{Al} / \mathrm{WO}_{3}$ and an ITO counter electrode. The two electrodes were brought into contact by an electrolyte $(0.1 \mathrm{M}$ lithium perchlorate in a propylene carbonate solution), the whole being sealed with silicone. A positive voltage and then a negative voltage were applied to the EC device. The change of sign of potential causes the expected electrochemical reaction and the resulting color change was visible with naked eye. This color change was quantified through the transmission spectra. Figure 15 shows that depending on the applied voltage the device transmits light or conversely becomes more and more opaque. In fact, in order to achieve reproducible results it was necessary to sputter $1 \mathrm{~nm}$ of Pt onto the $\mathrm{Cu}$ :Al layer before depositing the second $\mathrm{WO}_{3}$ layer. Without this protective Pt layer the $\mathrm{WO}_{3} / \mathrm{Ag} / \mathrm{Cu}: \mathrm{Al} / \mathrm{WO}_{3}$ electrode lost its conductive properties during the first cycle and the EC effect disappears. For comparison a device using TWO electrode is also reported as reference. It can be seen that the greater color change is obtained with the $\mathrm{WO}_{3} / \mathrm{Ag} / \mathrm{Cu}: \mathrm{Al} / \mathrm{Pt} / \mathrm{WO}_{3}$ EC-electrode . Unfortunately, in the small wavelength range, the Pt layer strongly perturbs the light transmission.

This preliminary study shows the feasibility of EC windows using D/M/D electrodes, opening up prospects for technology transfer to the market 


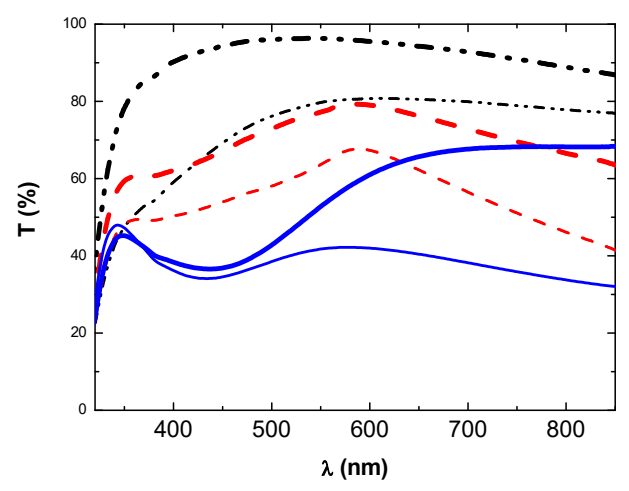

Figure 15: Coulour change induced by polarization inversion in different EC-devices :

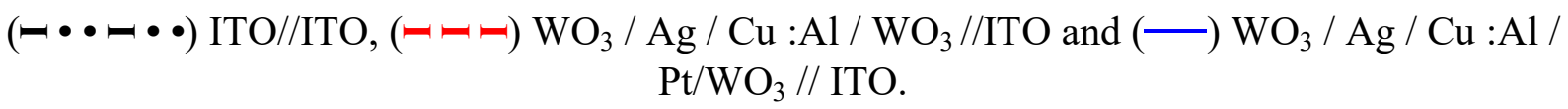

\section{CONCLUSION}

In the first part of the chapter reporting experimental results, we present the general properties, conductivity, transmission, surface roughness, adhesion to glass and plastic substrates, surface roughness, flexibility... of $\mathrm{D} / \mathrm{Ag} / \mathrm{D}$ structures using a transition metal oxide as dielectric. These properties are encountered in these structures using Ag as metal whatever the dielectric is. It can be concluded that these structures have promising future as NTCFE, as shown by the fact that the efficiency of OPVCs using this new electrode is equal to that of OPVCs using ITO. However, due to the limited reserves of Ag on earth, and therefore due to the price of $\mathrm{Ag}$ will be brought to increase in the future, it is already necessary to look for other metal. After $\mathrm{Ag}, \mathrm{Cu}$ is the most conductive metal. Therefore it deserves interest, but its tendency to diffuse in oxides is a bottleneck for future use in $\mathrm{D} / \mathrm{M} / \mathrm{D}$ structures. To overpass this difficulty, instead of using pure $\mathrm{Cu}$ we substituted it an alloy such as $\mathrm{Cu}: \mathrm{Ni}$ and $\mathrm{Cu}: \mathrm{Al}$. If $\mathrm{Ni}$ is efficient in limiting $\mathrm{Cu}$ diffusion, our choice to use only the simple evaporation technique limits the percentage of $\mathrm{Ni}$ which can be introduced into the alloy. That result in limiting the stabilization efficiency using this alloy. Therefore the $\mathrm{Cu}: \mathrm{Al}$ alloy was then probed, the melting point of $\mathrm{Al}$ being closer to that of cu than that of the Ni. If the introduction of 2 at.\% - 3 at.\% of $\mathrm{Al}$ allows obtaining transparent and conductive electrodes, it turns out to be necessary to introduce a thin $\mathrm{Ag}$ layer at the interface $\mathrm{WO}_{3} / \mathrm{Cu}: \mathrm{Al}$ to stabilize the properties of the structures. It appears that Ag diffuse all along the Cu layer, which stabilizes the properties of the electrodes. Therefore we are now realizing and studying the properties of $\mathrm{WO} 3 / \mathrm{Cu}: \mathrm{Ag} / \mathrm{WO} 3$ structures, using $\mathrm{CuAg}$ alloy as metal source.

Acknowledgements: The authors acknowledge funding from the European Community ERANETMED_ENERG-11-196

\section{References}

[1] C. G. Granqvist, Transparent conductors as solar energy materials : a panoramic review, Sol. Energy Mater. Sol. Cells 91 (2007) 1529-1598

[2] L. Zhang, J. M. Cole, Dye aggregation in dye-sensitized solar cells, J. Mater. Chem. A (2017). DOI: 10.1039/C7TA05632J

[3] Y. Li, G. Xsu, C. Cui, Y. Li, Flexible and Semitransparent Organic Solar Cells, Adv. Energy Mater. 8 (2018) 1701791 (1-28). 
[4] C. G. Granqvist, A. Hultaker, Transparent and conducting ITO films: new developments and applications, Thin Solid Films 411 (2002) 1-5.

[5] J. Lewis, S. Grego, B. Chalamala, E. Vick, D. Temple, Temple, Highly flexible transparent electrodes for organic light-emitting diode-based displays, Appl. Phys. Lett. 85 (2004) 3450-3452.

[6] Y.-M. Chang, L. Wang, W.-F. Su, Polymer solar cells with poly(3,4ethylenedioxythiophene) as transparent anode, Organic Electronics 9 (2008) 968-973.

[7] C.D. Williams, R.O. Robles, m. Zhang, S. Li, R.H. Baughman, A.A. Zakhidov, Appl. Phys. Lett. 93 (2008) 183506.

[8] M.-G. Kang, M.-S. Kim, L. J. Guo, Organic Solar Cells Using Nanoimprinted Transparent Metal Electrodes, Advanced Matrials 20 (2008) 4408-4413.

[9] H. Liu, V. Avrutin, N. Izyumskaya, Ü. Özgür, H. Morkoç, Transparent conducting oxides for electrode applications in light emitting and absorbing devices, Superlattices and Microstructures 48 (2010) 458-484.

[10] K. Sivaramakrishnan, T.L. Alford, Metallic conductivity and the role of copper in $\mathrm{ZnO} / \mathrm{Cu} / \mathrm{ZnO}$ thin films for flexible electronics, Appl. Phys. Lett. 94 (2009) 052104.

[11] D. Angmo, F. C. Krebs, Flexible ITO-free polymer solar cells, J. Appl. Poly. Sci. 2013, DOI: 10.1002/APP.38854

[12] C.-K. Cho, W.-J. Hwang, K. Eun, S.-H. Choa, S-I. Na, H.-K. Kim, Mechanical flexibility of transparent PEDOT:PSS electrodes prepared by gravure printing for flexible organic solar cells, Sol. Energy Mater. Sol. Cells 95 (2011) 3269-3275.

[13] N. Espinosa, R. Garcia-Valverde, A. Urbina, F. Lenzmann, M. Manceau, D. Angmo and F. C. Krebs, Life cycle assessment of ITO-free flexible polymer solar cells prepared by roll-to-roll coating and printing, Sol. Energy Mater. Sol. Cells 97, (2012) 3-13.

[14] M. L. Machana, L. Mueller-Meskamp, S. Gang, S. Olthof, and K. Leo, On-substrate polymerization of solution-processed, transparent PEDOT:DDQ thin film electrodes with a hydrophobic polymer matrix, Org. Electron. 12, (2011) 1518-1526.

[15] R. J. Peh, Y. Lu, F. Zhao, C.-L. Ken Lee, and W. L. Kwan, Vacuum-free processed transparent inverted organic solar cells with spray-coated PEDOT:PSS anode, Sol. Energy Mater. Sol. Cells 95, (2011) 3579-3584.

[16] R. Garg, S. Elmas, T. Nann, M. R. Andersson, Deposition Methods of Graphene as Electrode Material for Organic Solar Cells, Adv. Energy Mater. 2016, 1601393

[17] W. Cao, J. Li, H. Chen, J. Xue, Transparent electrodes for organic optoelectronic devices: a review, Journal of Photonics for energy 4 (2014) 040990-1-28.

[18] D. Bellet, M. Lagrange, T. Sannicolo, S. Aghazadechors, V. H. Nguyen, D. P. Langley, D. M. Muñoz-Rojas, C. Jimenez, Y. Bréchet, N. D. Nguyen, Transparent Electrodes Based on Silver Nanowire Networks: From Physical Considerations towards Device Integration, Materials 10 (2017) 570.

[19] J. Kwon, Y. D. Suh, J. Lee, S. Han, S. Hong, J. Yeo, H. Lee, S. H. Ko, Recent progress in silver nanowire based flexible/wearable optoelectronics, J. Mater. Chem. C 6 (2018) 7445-7461.

[20] H. Lu, X. Ren, D. Ouyang, W. C. H. Choy, Emerging Novel Metal Electrodes for Photovoltaic Applications, Small, (2018) 1703140 (1-40).

[21] Ghosh DS, Formica N, Chen TL, Hwang J, Eickhoff C, Pruneri V., Cu3Ag alloy capped with Ni transparent electrodes for indium-free organic photovoltaic and lighting devices, Sol Energy Mater Sol Cells 116 (2013) 89-93. 
[22] Formica N, Ghosh DS, Carrilero A, Chen TL, Simpson RE, Pruneri V. Ultrastable and Atomically Smooth Ultrathin Silver Films Grown on a Copper Seed Layer, ACS Appl Mater Interfaces $2013 ; 5: 3048-3053$.

[23] A. Indluru, T.L. Alford, Effect of Ag thickness on electrical transport and optical properties of indium tin oxide-Ag-indium tin oxide multilayers, J. Appl. Phys. 105 (2009) 123528.

[24] D.R. Sahu, S.-Y. Lin, J.-L. Huang, Investigation of conductive and transparent Al-doped $\mathrm{ZnO} / \mathrm{Ag} / \mathrm{Al}$-doped $\mathrm{ZnO}$ multilayer coatings by electron beam evaporation, Thin Solid Films 516 (2008) 4728-4732.

[25] D.R. Sahu, J.-L. Huang, The properties of $\mathrm{ZnO} / \mathrm{Cu} / \mathrm{ZnO}$ multilayer films before and after annealing in the different atmosphere, Thin solid Films 516 (2007) 208-211.

[26] K.-H. Choi, H.-J. Nam, J.-A Jeong, S.-W. Cho, H.-K. Kim, J.-W. Kang, D.-G. Kim, W.-J. Cho,

Highly flexible and transparent $\mathrm{InZnSnO} x \mathrm{Ag} / \mathrm{nnZnSnO} x$ multilayer electrode for flexible organic light emitting diodes, Appl. Phys. Lett. 92 (2008) 223302.

[27] L.L. Yang, D. Ge, H. Wei, F. He, X.D.He, Morphology and characterization of ITO-Ag-ITO films on fibers by layer-by-layer method, Appl. Surf. Sciences 255 (2009) 8197.

[28] S.H. Mohamed, S.A. Ahmed, Ellipsometrically determination of the optical constants of $\mathrm{ZnO}$ in $\mathrm{ZnO} / \mathrm{Ag} / \mathrm{ZnO}$ multilayer system, Eur. Phys. J. Appl. Phys. 44 (2008) 137.

[29] M. Fahland, T. Vogt, W. Schoenberger, N. Schiller, Optical properties of metal based transparent electrodes on polymer films, Thin Solid films 516 (2008) 5777-5780.

[30] M. Chakaroun, B. Lucas, B. Ratier, C. Defranoux, J.P. Piel, M. Aldissi, High quality transparent conductive electrodes in organic photovoltaic devices, Thin Solid films 518 (2009) 1250-1253.

[31] K.S. Yook, S.O. Jeon, C.W. Joo, J.Y. Lee, Transparent organic light emitting diodes using a multilayer oxide as a low resistance transparent cathode, Appl. Phys. Lett. 93 (2008) 013301.

[32] H.C. Cho, C. Yun, J.-W. Park, S. Yoo, Highly flexible organic light-emitting diodes based on $\mathrm{ZnS} / \mathrm{Ag} / \mathrm{WO}_{3}$ multilayer transparent electrodes, Organic Electronic 10 (2009)1163-1169.

[33] C. Tao, G. Xie, C. Liu, X. Zhang, W. Dong, F. Meng, X. Kong, L. Shen, S. Ruan, W. Chen. Semitransparent inverted polymer solar cells with $\mathrm{MoO} 3 / \mathrm{Ag} / \mathrm{MoO} 3$ as transparent electrode, Appl. Phys. Lett. 95 (2009) 053303

[34] L. Cattin, M. Morsli, F. Dahou, S. Yapi Abe, A. Khelil, J.C. Bernède, Investigation of low resistance transparent $\mathrm{MoO}_{3} / \mathrm{Ag} / \mathrm{MoO}_{3}$ multilayer and application as anode in organic solar cells, Thin Solid Films, 518 (2010) 4560-4563.

[35] V. Shrotriya, G. Li, Y. Yao, C.-W. Chu, and Y. Yang, Transition metal oxides as the buffer layer for polymer photovoltaic cells, Appl. Phys. Lett. 88, p. 073508, 2006.

[36] A. G. F. Janssen, T. Riedl, S. Hamwi, H.-H. Johannes, and W. Kowalsky, Highly efficient organic tandem solar cells using an improved connecting architecture, Appl. Phys. Lett. 91(7), p. 073519, 2007,

[37] C-H. Chou, W. L. Kwan, Z. H Y. Yang, A Metal-Oxide Interconnection Layer for Polymer Tandem Solar Cells with an Inverted Architecture, Adv. Mater. 23 (2011) 1282-1286.

[38] S. Lee, T. E. Kang, D. Han, H. Kim, B. J. Kim, Polymer/small-molecule parallel tandem organic solar cells based on $\mathrm{MoOx}-\mathrm{Ag}-\mathrm{MoOx}$ intermediate electrodes, Sol. Energy Mater. Sol. Cells 137 (2015) 34-43.

[39] S. Bogati, A. Georg, W. Graf, Photoelectrochromic devices based on sputtered $\mathrm{WO}_{3}$ and $\mathrm{TiO}_{2}$ films, Sol. Energy Mater. Sol. Cells 163 (2017) 170-177. 
[40] Hyun Suk Jung * and Nam-Gyu Park, Perovskite Solar Cells: From Materials to Devices, Small 2015, 11, No. 1, 10-25

[41] L. M. Wheeler, D. T. Moore, R. Ihly, N. J. Stanton, E. M. Miller, R. C. Tenent, J. L. Blackburn, N. R. Neale, Switchable photovoltaic windows enabled by reversible photothermal complex dissociation from methylammonium lead iodide, Nature Communicationsvolume 8, Article number: 1722 (2017)

[42] W. Wu, W. Lin, J. Bao, Z. Liu, B. Liu, K. Qiu, Y. Chen, H. Sen, Dopant-free multilayer back contact silicon solar cells employing $\mathrm{V}_{2} \mathrm{O}_{x} /$ metal $/ \mathrm{V}_{2} \mathrm{O}_{x}$ as an emitter, RSC Adv. 7 (2017) 23851-23858.

[43] LG Gerling, S Mahato, A Morales-Vilches, G Masmitja, P Ortega, C Voz, R. Alcubilla, J. Puigdollers, Transition metal oxides as hole-selective contacts in silicon heterojunctions solar cells, Solar Energy Materials and Solar Cells 145 (2016) 109115.

[44] M. Theuring, M. Vehse, K. Von Medel, C. Agert, AZO-Ag-AZO transparent electrode for amorphous silicon solar cells, Thin Solid Films 558 (2014) 294-297

[45] N. C. Davy, M. Sezen-Edmonds, J. Gao, X. Lin, A. Liu, N. Yao, A. Kahn, Y-L. Loo, Pairing of near-ultraviolet solar cells with electrochromic windows for smart management of the solar spectrum Nature energy2 (2017) 17104, .

[46] M. Hssein, S. Tuo, S. Benayoun, L. Cattin, M. Morsli, Y. Mouchaal, M. Addou, A. Khelil, J.C. Bernède, $\mathrm{Cu}$-Ag bi-layer films in dielectric/metal/dielectric transparent electrodes as ITO free electrode in organic photovoltaic devices, Organic Electronics 42 (2017) 173-180.

[47] Y. Berredjem, N. Karst, L. Cattin, A. Lkhdar-Toumi, A. Godoy, G. Soto, F. Diaz, M.A. del Valle, M. Morsli, A. Drici, A. Boulmokh; A.H. Gheid, A. Khelil, J.C. Bernède. Plastic photovoltaic cells encapsulation, effect on the open circuit voltage. Dyes and Pigments 78 (2008) 148-156.

[48] X. Liu, X. Cai, J. Qiao, J. Mao, N. Jiang, The design of ZnS/Ag/ZnS transparent conductive multilayer films, Thin Solid Films 441 (2011) 200-206.,

[49] C. Guillén and J. Herrero, TCO/metal/TCO structures for energy and flexible electronics, Thin Solid Films 520 (2011) 1-17.

[50] L. Cattin, J. C. Bernède, M. Morsli, Toward indium-free optoelectronic devices: Dielectric / Metal / Dielectric alternative conductive transparent electrode in organic photovoltaic cells Phys. Status Solidi A 210 (2013) 1047-1061.

[51] I. Pérez Lopéz, L. Cattin, D.-T. Nguyen, M. Morsli, J.C. Bernède, Dielectric/metal/dielectric structures using copper as metal and $\mathrm{MoO}_{3}$ as dielectric for use as transparent electrode, Thin Solid Films 520 (2012) 6419-6423.

[52] G. Haacke, New figure of merit for transparent conductors, J. App. Phys. 47 (1976) 4086-4089.

[53] Adrien Bou, Philippe Torchio, Sylvain Vedraine, Damien Barakel, Bruno Lucas, JeanChristian Bernède, Pierre-Yves Thoulon, Marc Ricci, Numerical optimization of multilayer electrodes without indium for use in organic solar cells, Solar Energy Materials \& Solar Cells 125 (2014) 310-317.

[54] F. Li, S. Ruan, Y. Xu, F. Meng, J. Wang, W. Chen, and L. Shen, Semitransparent inverted polymer solar cells using $\mathrm{MoO}_{3} / \mathrm{Ag} / \mathrm{WO}_{3}$ as highly transparent anodes, Sol. Energy Mater. Sol. Cells 95, 877-880 (2011)

[55] L. Cattin, Y. Lare, M. Makha, M. Fleury. Chandezon, T. Abachi, M. Morsli, K. Napo, M. Addou, J.C. Bernède, Effect of the Ag deposition rate on the properties of conductive transparent $\mathrm{MoO}_{3} / \mathrm{Ag} / \mathrm{MoO}_{3}$ multilayers, Solar Energy Materials \& Solar Cells 117 (2013) 103-109 
[56] M. Hssein, S. Tuo, S. Benayoun, L. Cattin, M. Morsli, Y. Mouchaal, M. Addou, A. Khelil, J. C. Bernède, $\mathrm{Cu}-\mathrm{Ag}$ bi-layer films in dielectric/metal/dielectric transparent electrodes as ITO free electrode in organic photovoltaic devices, Organic Electronics 42 (2017) 173-180.

[57] L. Cattin, El Jouad, N. Stephant, G. Louarn, M. Morsli, M. Hssein, Y. Mouchaal, S. Thouiri, M. Addou, A. Kheli, J. C. Bernède, Dielectric/Metal/Dielectric alternative transparent electrode: Observations on stability/degradation, Journal of Physics D: Applied Physics 50 (2017) 375502 (13pp).

[58] Ross R C 1990 Observations on humidity-induced degradationof Ag-based lowconductivity films Sol. Energy Mater.21 25-42

[59] H. Essaidi, L. Cattin, Z. El Jouad, S. Touihri, M. Blais, E. Ortega, G. Louarn, M. Morsli, T. Abachi, T. Manoubi, M. Addou, M. A. del Valle, F. Diaz, J. C. Bernède, Indium free electrode, highly flexible, transparent and conductive for optoelectronic devices, Vaccum 153 (2018) 225-231.,

[60] S. Tuo, L. Cattin, H. Essaidi, L. Peres, G. Louarn, Z. El Jouad, M. Hssein, S. Touihri, S. Yapi Abbe, P. Torchio, M. Addou, J. C. Bernède, Stabilisation of the electrical and optical properties of dielectric/ $\mathrm{Cu} /$ dielectric structures through the use of efficient dielectric and Cu:Ni alloy, Journal of Alloys and Compounds 729 (2017) 109-116.

[61] G. Leftheriotis, P. Yianoulis, D. Patrikios, Deposition and optical properties of optimised $\mathrm{ZnS} / \mathrm{Ag} / \mathrm{ZnS}$ thin films for energy saving applications, Thin Solid Films 306 (1997) 92-99.

[62] C. G. Granquist, Radiative heating and cooling with spectrally selective surface, Appl. Opt. 20 (1981) 2606-2615.

[63] O. Ergun, S. Coskun, Y. Yusufoglu, H. E. Unalan, High-performance, bare silver nanowire network transparent heaters, Nanotechnology 27 (2016) 445708.

[64] K. Chiba, K. Suzuki, Effects of heterogeneous metal atoms on the stability of a silver layer of a heat mirror coating, Sol. Energy Mater. Sol. Cells 25 (1992) 113-123.

[65] H. Han, T.L. Alford, Texture and surface morphology evolution of $\operatorname{Ag}(\mathrm{Cu})$ layers on indium tin oxide thin films, J. Phys. D. Appl. Phys. 41 (2008), 155306.

[66] Z. Bi, X. Li, X. He, Y. Chen, X. Xu, X. Gao, Sol. Integrated electrochromism and energy storage applications based on tungsten trioxide monohydrate nanosheets by novel one-step low temperature synthesis, Energy Mater. Sol. Cells 183 (2018) 59-65) 